\title{
Upper gastrointestinal bleeding, chronic pancreatitis and a near miss
}

\author{
Ella Ferdinand, ${ }^{1}$ Homoyoon Mehrzad, ${ }^{2}$ Ashish Awasthi ${ }^{1}$
}

${ }^{1}$ Department of

Gastroenterology, Walsall

Healthcare NHS Trust, Walsall, UK

${ }^{2}$ Department of Radiology, University Hospital

Birmingham, Birmingham, UK

\section{Correspondence to} Dr Ella Ferdinand, ella.mozdiak@nhs.net
To cite: Ferdinand $\mathrm{E}$, Mehrzad H, Awasthi A. BMJ Case Rep Published online: [please include Day Month Year] doi:10.1136/bcr-2013010420

\section{DESCRIPTION}

A 43-year-old man presented with a 2-day history of haematemesis and melaena. His medical history included chronic pancreatitis and alcohol-induced liver cirrhosis.

Gastroscopy revealed a small amount of blood in the duodenum but no bleeding source. Following endoscopy, he remained stable but his haemoglobin dropped from 9.8 to $7.8 \mathrm{~g} / \mathrm{dL}$ in 4 days. A repeat endoscopy was also unremarkable.

The following day he developed severe abdominal pain and haemodynamic instability. An urgent CT of the abdomen was performed (figure 1). This demonstrated a large gastroduodenal artery pseudoaneurysm. This was successfully treated with aneurysmal embolisation. Figure 2A,B demonstrates the pre-embolisation and postembolisation images.

Pseudoaneurysm of the gastroduodenal artery is an uncommon complication of chronic pancreatitis occurring in approximately $5 \%$ of cases. ${ }^{1}{ }^{2}$ Aneurysmal disease most often affects splenic, gastroduodenal and pancreaticoduodenal arteries. ${ }^{3}$ It is caused by visceral arterial exposure to proteolytic pancreatic enzymes, causing a local arteritis with resultant damage to the vessel wall, more commonly observed in chronic pancreatitis. ${ }^{2}$ When associated with bleeding it can be rapidly fatal even if detected early. $^{3}$ Pain and gastrointestinal haemorrhage are common presenting symptoms. Endoscopy is often unsuccessful in locating the source of bleeding and CT angiography is the diagnostic test of choice.

(a)

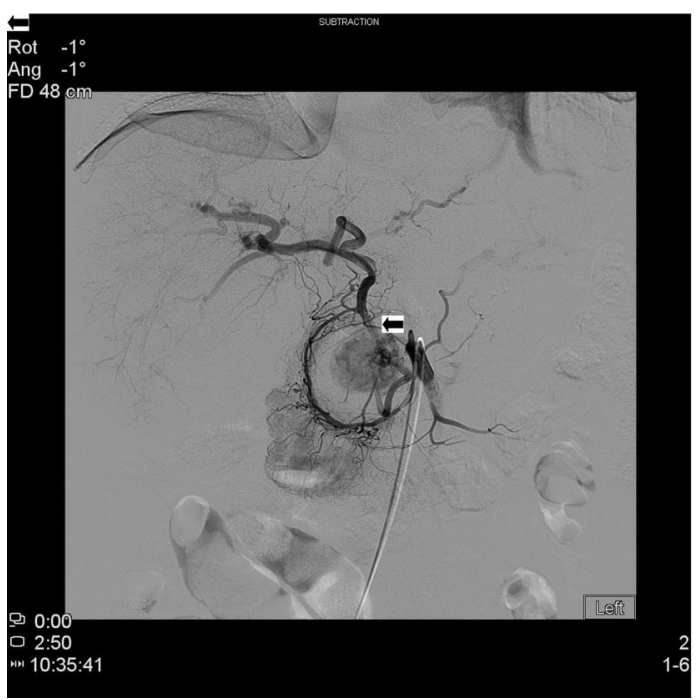

(b)

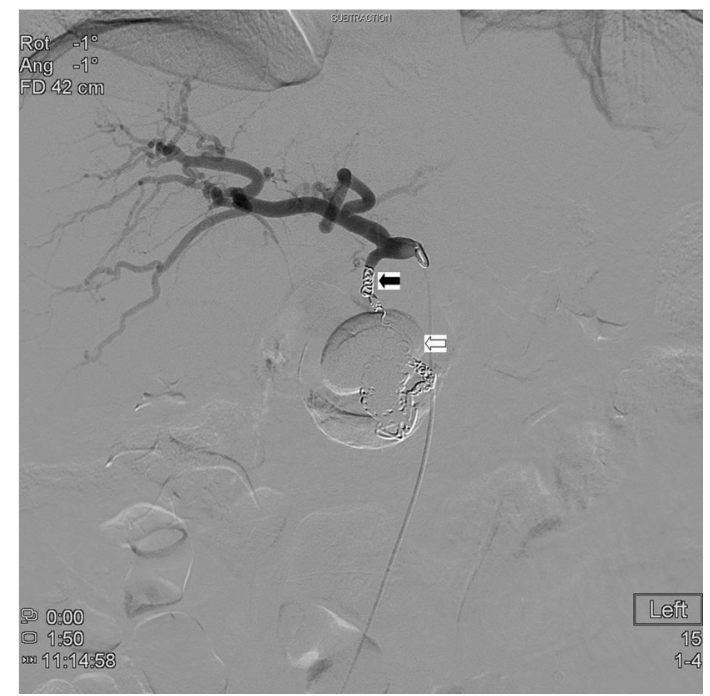

Figure 2 (A) Pre-embolisation angiogram demonstrates contrast filling the large central pseudoaneurysm arising from the gastroduodenal artery (GDA) (arrow). (B) Embolisation coils (black arrow) were inserted to stop flow into the pseudoaneurysm sac from the GDA. A check angiogram demonstrates no flow into the pseudoaneurysm sac (white arrow).

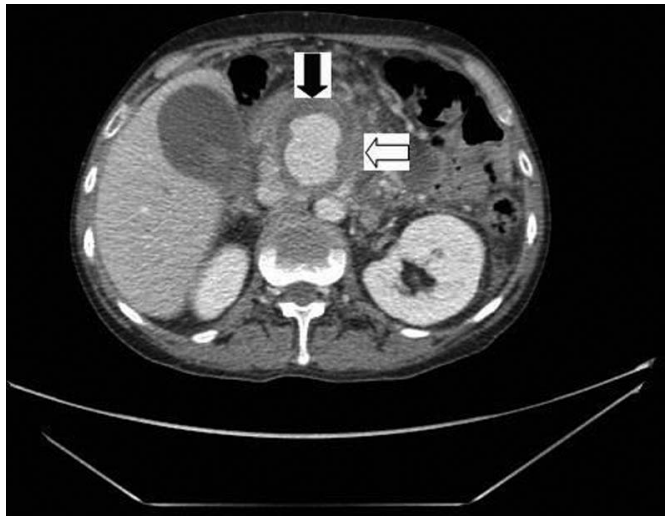

Figure 1 An axial venous phase abdominal CT with contrast at the level of the gallbladder demonstrates a large central pseudoaneurysm arising from the gastroduodenal artery (black arrow), with surrounding inflammatory change (white arrow).

Reliance on endoscopy alone can lead to a missed diagnosis.

Management includes aneurysmal embolisation and surgical repair. Embolisation using arteriography is the first-line treatment, with success rates of $75-88 \% .^{2}{ }^{3}$ Surgical approaches, including partial pancreatectomy or arterial ligation are reserved for cases where embolisation is unsuccessful. ${ }^{1}$ 


\section{Learning points}

- Upper gastrointestinal bleeding is a common medical emergency and endoscopy remains the primary diagnostic investigation. However, reliance on endoscopy alone may miss a potentially life-threatening diagnosis.

- In chronic pancreatitis, significant upper gastrointestinal bleeding is most often associated with peptic ulcer disease and complications of portal hypertension related to coexisting liver cirrhosis.

- Although uncommon, pseudoaneurysm formation should be considered and investigated using CT imaging if upper gastrointestinal endoscopy is normal.
Contributors EF and AA drafted the manuscript and performed the literature search. HM provided images and descriptions of the images. All the authors critically revised the article.

Competing interests None.

Patient consent Obtained.

Provenance and peer review Not commissioned; externally peer reviewed.

\section{REFERENCES}

1 Klaus M, Heye T, Stampfl U, et al. Successful arterial embolisation of a giant pseudoaneurysm of the gastroduodenal artery secondary to chronic pancreatitis with literature review. J Radiol Case Rep 2012;6:9-16.

2 Bergert $\mathrm{H}$, Hinterseher I, Kersting $\mathrm{S}$, et al. Management and outcome of haemorrhage due to arterial pseudoaneurysms in pancreatitis. J Surgery 2005; 137:323-8

3 Balthazar EJ, Fisher LA. Hemorrhagic complications of pancreatitis: radiologic evaluation with emphasis on CT imaging. Pancreatology 2001;1:306-13.

Copyright 2013 BMJ Publishing Group. All rights reserved. For permission to reuse any of this content visit http://group.bmj.com/group/rights-licensing/permissions.

BMJ Case Report Fellows may re-use this article for personal use and teaching without any further permission.

Become a Fellow of BMJ Case Reports today and you can:

- Submit as many cases as you like

- Enjoy fast sympathetic peer review and rapid publication of accepted articles

- Access all the published articles

- Re-use any of the published material for personal use and teaching without further permission

For information on Institutional Fellowships contact consortiasales@bmjgroup.com

Visit casereports.bmj.com for more articles like this and to become a Fellow 